\title{
Foreign Language Anxiety (FLA) in English Language Classroom
}

\author{
Wan Iman Wan Salim, Vijayaletchumy Subramaniam, and Arbaayah Ali Termizi
}

\begin{abstract}
The study aims to examine Foreign Language Anxiety (FLA) among learners of English language at Universiti Kuala Lumpur Malaysia France Institute (UniKL MFI). The study focuses on analyzing factors of FLA and learners' coping strategies. Components of FLA proposed by Horwitz et al. (1986) served as the theoretical framework for this research. Foreign Language Classroom Anxiety Scale (FLCAS) developed by Horwitz et al. (1986) was administered to 160 students who enrolled in the English course, Fundamental English (WEB10302) during semester September-December 2013. An interview was conducted to obtain better understanding of this psychological phenomenon. The results indicated that learners regardless of gender and language proficiency - experience a certain degree of FLA in English classroom. To cope with FLA, learners were found to prefer working in groups and seeking assistance from classmates who are more proficient. Learners were also found to adopt debilitating strategies such as minimizing class participation and occupying back seats in the class. The findings recommend language instructors to acknowledge the existence of FLA in order to facilitate English language learning. By doing so, a more effective teaching approach can be structured to promote a less threatening learning experience
\end{abstract}

Index Terms-Language anxiety, English language learning, coping strategies, classroom activities

\section{INTRODUCTION}

In answering to the country's demand to produce more skilled workers who are highly competent in both local and global industrial sectors, technical institutions of higher learning in Malaysia, such as Universiti Kuala Lumpur Malaysia France Institute (UniKL MFI), are driven to equip its graduates with profound technical and English communication skills. To continuously improve learners' English proficiency, UniKL MFI has made it compulsory for all its Bachelor students to complete three levels of English language courses: 1) Fundamental English (WEB10302), 2) Professional English 1 (WEB20202) and, 3) Professional English 2 (WEB20302). A variety of classroom activities are

Manuscript received November 11, 2016; revised March 19, 2017.

Wan Iman Wan Salim is with English Unit, Universiti Kuala Lumpur Malaysia France Institute (UniKL MFI), Section 14, Jalan Teras Jernang, 43650 Bandar Baru Bangi, Selangor, Malaysia (e-mail: waniman74@gmail.com).

Vijayaletchumy Subramaniam is with Department of Malay Language, Faculty of Modern Languages and Communication, Universiti Putra Malaysia, 43400 Serdang, Selangor, Malaysia (e-mail: letchumy1617@gmail.com).

Arbaayah Ali Termizi is with Department of English Language and Literature, Faculty of Modern Languages and Communication, Universiti Putra Malaysia, 43400 Serdang, Selangor, Malaysia (e-mail: arbaayah@upm.edu.my). introduced to enhance learners' command of English. Learners' performances are measured based on the activities performed individually or in groups. Despite efforts from the university to enhance students' mastery of the language, UniKL MFI students, in general, were found to be passive and lacking the confidence to communicate in English. Students shy away from using the language and have to be occasionally reminded to use English even when attending English classes. Since English is the medium of instruction in UniKL MFI, it is feared that poor command of English can negatively impact students' academic performance as a whole. English language learning can be influenced by some factors and one of these factors is Foreign Language Anxiety (FLA) - an anxiety specific to second or foreign language (L2) learning. The study thus, aims to investigate factors of FLA among UniKL MFI English language learners and to identify their strategies in coping with FLA.

\section{BACKGROUND OF RESEARCH}

Researchers around the world acknowledge feelings such as uneasiness, anxious, crippled, inadequate and lack of confidence as common among non-native English learners. Spielberger (1983) defines anxiety as the "subjective feeling of tension, apprehension, nervousness, and worry associated with an arousal of the autonomic nervous system" (125) [1]. By this definition, any individual can become anxious in a specific situation or position that pressures the emotion and psychology. Learning a L2 can be a specific situation most likely to induce anxiety. Previous studies [2]-[6] have suggested the unique and specific nature of L2 anxiety in comparison to anxiety experienced in other classes. In a L2 classroom, learners are expected to understand the lesson and instruction, and at the same time express themselves in a language they have less mastery of. L2 learners often believe L2 class gives them unnecessary traumatic experience. According to the feedback obtained by Kelly Hall \& Davies (1995), learners of Spanish as L2 reflect the class as, "boring", "hideous", and "awful" (5) [7]. Onwuegbuzie et al. (1999), who studied 210 learners taking L2 classes in universities in the United States, found the relationship between anxiety experienced by learners with their self-perception and self-concept. Learners who possess low confidence level early in language learning will feel more threatened and vulnerable in L2 classroom [8].

Horwitz et al. (1986), defined FLA as a "distinct complex of self-perceptions, beliefs, feelings, and behaviors related to classroom language learning arising from the uniqueness of the language learning process" (128) [1]. FLA is often experienced by learners when they are conscious of the 
demand to perform tasks in a language they have less command and control of. Learners are placed in a situation where they are forced to be aware that every words uttered or written stand corrected. Hence, their self-image and dignity are at stake as they are exposed to scrutiny and assumption. Though some researchers [9], [10] suggested the facilitating nature of anxiety, many more [1], [11], [12] are continuously proving the debilitating effects of FLA and its negative correlation with learners' performance. According to Campbell \& Ortiz (1991), FLA among learners of higher education institutions is alarming and they estimated that "anywhere from one-quarter to one-half of students" experience the harmful effect of FLA (159) [13].

Horwitz et al. (1986) believe this phenomenon can negatively affect learners' emotional reaction towards learning the language because they "have difficulty concentrating, become forgetful, swear and have palpitations" (126) [1]. Learners will be disappointed for their inability to express an opinion or provide the correct answer due to the lack of proficiency. They tend to commit mistakes when executing classroom activities despite having done prior preparation and practice. The effect of FLA is described by Cohen (1990) and Oxford \& Nyikos (1989) through Fig. 1 below (35-36) [7].

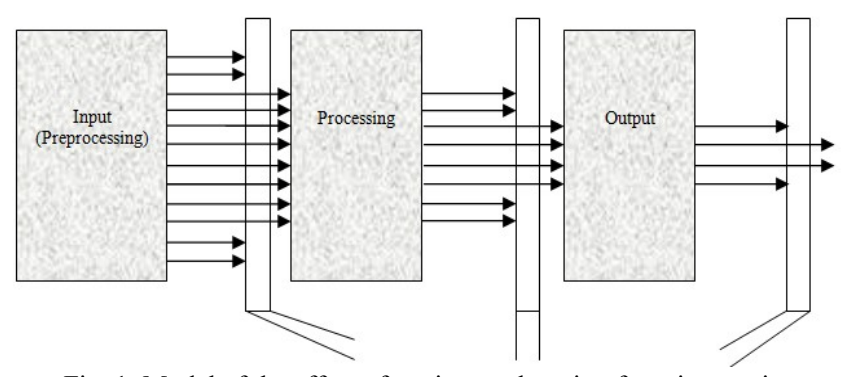

Fig. 1. Model of the effect of anxiety on learning from instruction.

Anxiety starts to interfere with learning process during the input stage. The existence of anxiety at this stage distracts the learners from learning new words, phrases and grammar. At the output stage, anxiety continues to hinder learners from processing the received input and thus, greatly affecting learners' ability to communicate. The learners might know the answer or the right word may be at the tip of the tongue, but the presence of anxiety prevents it from being put forward. Hence, the output is rendered very minimal and the learners' motivation to learn the language will negatively be affected.

In conceptualising FLA, Horwitz et al. (1986) proposed three components that contribute to language anxiety: 1) Communication Apprehension (CA), 2) Test Anxiety (TA), and 3) Fear of Negative Evaluation, (FNE). TA may lead learners into going blank and may hinder learners from answering despite prior preparation. While CA may interfere in learners' attempt to communicate, FNE can transcend the context of CA and TA as it posits itself in social situation and in the context where evaluation is carried out, such as when attending a job interview or speaking in L2 classes (127) [1]. Horwitz et al. suggested L2 classroom to be an anxiety provoking situation as it forces learners of L2 to interact with the complexities of self-perceptions, beliefs, feelings, and behaviors that intertwine with the technicalities of the language learning itself. Learners are quick to form presumptions towards language instructors and are easily apprehensive towards the instructors' and classmates' negative evaluation. With the fear to safeguard their self-image, learners become extra careful not to make mistakes to the extent they become too cautious and anxious to communicate. Learners are held back for over-thinking about their inability to express opinions clearly or correctly through the use of L2.

In the context of Malaysia, the English modules often place emphasis on correct grammar usage. Learners are constantly drilled with English grammar and are assessed through series of grammar quizzes and tests. Learners' language competent is inclined to be based on the scores attained in grammar tests. Researchers such as Trisha Dvorak (1986) concluded that, "writing improvements are unrelated to grammar study," and "intensive correction of student writing, which has a negative effect on writing in terms of student attitudes and motivation, has little positive effect at all" (151-152) [14]. Over-emphasis on grammar may induce anxiety as learners strive to speak English accurately. It is thus, not surprising to find a majority of Malaysian learners who excel in language tests but are less confident to speak.

\section{LITERATURE REVIEW}

Studies on FLA and how L2 learners cope with FLA has recently started to capture researchers' attention and FLCAS has been administered to learners of various L2 by researchers from different countries to measure FLA. Kondo \& Yang (2004) put forward five FLA coping strategy categories: 1) Preparation; 2) Relaxation; 3) Positive Thinking; 4) Peer Seeking; and 5) Resignation (262) [15]. These strategies were addressed in a study conducted by Ardi Marwan (2007) in investigating FLA among 77 English language learners in several universities in Indonesia. Marwan found learners employing four of the strategies, i.e., Preparation, Relaxation, Positive Thinking, and Peer Seeking to cope with FLA. Learners however, were not found to apply Resignation strategy such as sleeping or giving up. Marwan suggested for further research to be carried out to investigate how teachers' teaching can help reduce FLA (49-50) [16].

Terri Lee Nagahashi (2007) administered FLCAS and post-intervention survey to 38 freshman students in Akita University, Japan to examine FLA and techniques to reduce it. The findings suggested "cooperative learning strategies" as a technique to create less threatening learning environment effective for reducing FLA (61) [17]. Learners' CA can be reduced when they are provided with opportunities to speak in small groups along with supportive peers. Respondents were found to respond positively to activities performed with partners and groups members. The study suggested for further studies to examine the effectiveness of structured cooperative activities in improving the overall learning success (61) [17].

Yasin Nuranifar (2014) administered FLCAS to 125 students in Kosar and Khadijah pre-universities, Iran to examine FLA and learners coping strategies. The study identified 80 tactics learners employ to deal with FLA though no significant relationship was found between FLA and 
frequencies of strategy used. Respondents reported to choose at least one tactic in each of the five strategy clusters. Findings were as follows: Preparation (68.4\%); Relaxation (46.2\%); Positive Thinking (59.8\%); Peer Seeking (21.4\%); and Resignation (54.7\%) (1500) [18]. The study concluded that learners who face anxiety for assuming they lack skills may study harder. When learners perceive their anxiety to be too much to cope with, they may resort to Resignation and "not invest enough effort to reduce the anxiety" (1502) [18].

Learners' coping strategies were also discussed by Rochelle Irene Lucas et al. (2011) in a study conducted on learners of English in the Philippines [19]. The research adapted FLCAS and Language Strategy Survey (LSS) developed by Cohen, Oxford and Chi (2001) to analyze strategies taken by 250 students at several higher education institutions in Manila in dealing with FLA in learning English as L2. Using statistical analysis, the findings suggested that learners, in general, suffer from TA and FNE in learning English. The study identified that learners' adopted "vocabulary strategy" as it "enables the learners to take charge of their own learning" and allows learners to feel more confident when using L2 (113) [19]. The study suggested for further research on understanding learners' FLA and their coping strategies.

Keiko Iizuka (2010) also explored learners' strategies to deal with FLA [20]. Acknowledging the debilitating nature of FLA in L2 learning, Iizuka studied the strategies adopted by 108 students of EFL at several colleges in Japan. Respondents answered a set of questionnaire on the anxiety they experience in the context of learning English. Respondents were interviewed in Japanese language. Two questions asked were: "When do you experience anxiety in EC classes?" and "How do you cope with such anxiety?" (104) [20]. The researcher used KJ method which was developed by Kawakita Jiro (1967, 1970 ) to classify the answers obtained from the questionnaire. Through this method, the researcher identified 12 anxiety-provoking contexts in English classroom to include speaking in front of the class and communicating with classmates who are more proficient. The main factors identified to induce anxiety include, "difficulty in following teachers' (and classmates') talk" and "difficulty in making one's point in English" due to learners' limited vocabulary and unclear instruction given by the instructors (106) [20]. The results from this study indicated that Japanese learners adopt positive and negative strategies in dealing with FLA. Positively, FLA encouraged them to redouble their efforts and ensure early preparations are done before class. Learners were also found to seek answers from friends who are more proficient in the language. Nevertheless, there were learners who resort to negative attitude by "distancing" themselves from the stressful situation (109) [20]. The findings of this study closely match the findings of a research conducted by Spielmann \& Randofsky (2001) that revealed learners adopting "non-active strategy" by distancing themselves from any difficulties and by trying to ignore the situation (272) [10] Pappamihiel (2002) also found that learners who experience FLA adopted avoidance strategy for the fear of making mistakes and they were found to avoid speaking in class (345) [21]. Another strategy identified by Iizuka was learners' strategy to use Japanese language (L1) in difficult situations.
According to Iizuka, this strategy can be both positive and negative as usage of L1 has to be limited for effective L2 learning. The study suggested for the questionnaire adapted to be revised to obtain clearer data while recommending for further research to develop specific criterion to assess coping strategies used by learners with FLA.

\section{RESEARCH METHODOLOGY}

\section{A. Research Sample}

This study was carried out in Universiti Kuala Lumpur Malaysia France Institute (UniKL MFI), a technical university situated in Selangor, Malaysia. 160 learners who enrolled in the English course, Fundamental English (WEB10302) for 14 weeks were involved as respondents and were asked to complete the questionnaire FLCAS. Out of 160 respondents, 24 volunteered to be interviewed. The volunteers were also requested to identify ten strategies they most commonly used to deal with FLA.

\section{B. Research Instruments}

The study adapted the questionnaire FLCAS developed by Horwitz et al. (1986). FLCAS, designed to specifically evaluate learners' anxiety in a specific context of a foreign language classroom, has been a popular instrument used by researchers across the globe [22]-[30]. For the purpose of this study, items in FLCAS were translated into Malay language to assist respondents' comprehension. 33 items of FLCAS were identified to assess components of FLA as proposed by Horwitz et al. [9]: 1) Communication Apprehension, 2) Test Anxiety; and 3) Fear of Negative Evaluation. This study introduced Fear of Language Class (FLC) as another component of FLA. Items listed in FLCAS were identified and categorized into four components of FLA as listed in Table I below. Data obtained were analyzed using Statistical Package for Social Science (SPSS).

TABLE I: COMPONENTS OF FLA DERIVED FROM FLCAS

\begin{tabular}{llc}
\hline \multicolumn{1}{c}{ Component of FLA } & \multicolumn{1}{c}{ Item No } & Total Item \\
\hline Communication & $1,3,4,9,14,15,18,20,27,29$, & 13 \\
Apprehension (CA) & $30,32,33$ & \\
\hline Test Anxiety (TA) & $8,10,21,22$, & 4 \\
\hline $\begin{array}{l}\text { Fear of Negative } \\
\text { Evaluation (FNE) }\end{array}$ & $2,7,13,19,23,24,31$ & 7 \\
\hline $\begin{array}{l}\text { Fear of Language } \\
\text { Class (FLC) }\end{array}$ & $5,6,11,12,16,17,25,26,28$ & 9 \\
\hline
\end{tabular}

An interview was also carried out to obtain insights into FLA. Respondents of FLCAS were asked to list common strategies they employ to deal with FLA. The strategies listed were collected and grouped into 22 common strategies. A checklist consisting of 22 strategies were distributed to 24 respondents who volunteered to be interviewed. Respondents were asked to select ten most common strategies they employ in dealing with FLA.

\section{FINDINGS AND DISCUSSION}

\section{A. Research Demographic Profile}

The study involved Bachelor degree students from various 
backgrounds. Demographic profile is explained in Table II.

Table II shows 160 respondents consisting of 132 (84.4\%) male students and $25(15.6 \%)$ female students were involved in this study. $35(21.9 \%)$ respondents reported to have working experience of more than 1 year while 125 (78.1\%) have no or less than 1 year of working experience. The study involved respondents from various technical engineering courses: $10(6.3 \%)$ are students from Air Conditioning and Industrial Refrigeration, 30 (18.8\%) from Automotive Maintenance, 16 (10.0\%) from Electric and Electronic, 52 (32.5\%) from Fabrication and Joining, 31 (19.4\%) from Industrial Automation, and 21 (13.1\%) from Machine and Maintenance. All respondents reported to have had learned English as L2 for more than 10 years.

\begin{tabular}{lll}
\multicolumn{3}{c}{ TABLE II: DEMOGRAPHIC PROFILE } \\
\hline Demography & $\begin{array}{l}\text { Frequency (f) } \\
\mathrm{N}=160\end{array}$ & $\begin{array}{l}\text { Percentage } \\
(\%)\end{array}$ \\
\hline Gender & 135 & $84.4 \%$ \\
\hline Male & 25 & $15.6 \%$ \\
\hline Female & & \\
\hline Working Experience & 35 & $21.9 \%$ \\
\hline More than 1 year & 125 & $78.1 \%$ \\
\hline Less than 1 year & & $6.3 \%$ \\
\hline Course & 10 & $18.8 \%$ \\
\hline $\begin{array}{l}\text { Air Conditioning and } \\
\text { Industrial Refrigeration }\end{array}$ & 30 & $10.0 \%$ \\
\hline Automotive Maintenance & 16 & $32.5 \%$ \\
\hline Electric and Electronic & 52 & $19.4 \%$ \\
\hline Fabrication and Joining & 31 & $13.1 \%$ \\
\hline Industrial Automation & 21 & \\
\hline $\begin{array}{l}\text { Machine } \\
\text { Maintenance }\end{array}$ & and & \\
\hline
\end{tabular}

\section{Language Spoken at Home}

As Malaysia is a multi-racial country, students of UniKL MFI originate from various cultures and races, thus resulting in the differences in the languages spoken at home.

TABLE III: LANGUAGE SPOKEN AT HOME

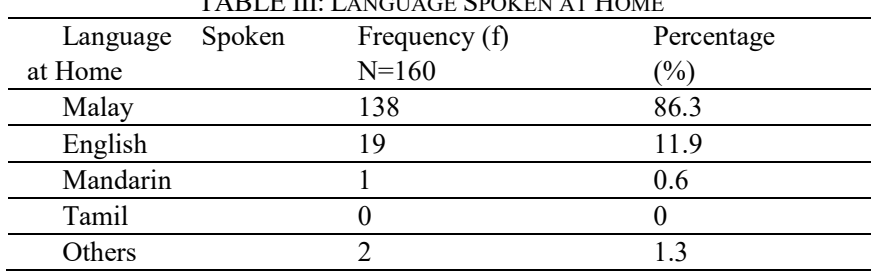

Table III shows the languages respondents primarily use at home. $138(86.3 \%)$ respondents reported to use Malay as the medium of communication at home, 19 (11.9\%) use English, $1(0.6 \%)$ uses Mandarin, no respondent ( $0 \%)$ uses Tamil, and $2(1.3 \%)$ respondents use other languages. Based on the interview, more than $90 \%$ of the respondents admitted to feel more comfortable speaking English with friends rather than with family members. A majority of the respondents confessed of not speaking English at home. Respondents reported of feeling ashamed and awkward to do so as nobody at home speaks English.

English Proficiency Level Based on Sijil Pelajaran Malaysia (SPM) Result

Malaysians are required to sit for the national examination, Malaysian Certificate of Examination or Sijil Pelajaran
Malaysia (SPM) in the fifth-year of secondary schools as an assessment before entering higher education institutions. The exam is set and examined by Malaysian Examinations Syndicate. The results are assigned to a grade point and a letter to each range, with $1 \mathrm{~A}$ ("1" being the grade point and "A" the letter grade) as the highest range and 9G the lowest.

Table IV shows respondents' results for English language subject in SPM. 21.9\% of the respondents obtained grade 5C while only $8.1 \%$ obtained grade $1 \mathrm{~A}$. Grades are classified into several levels as shown in Table V. Based on this classification, it can be concluded that respondents' grades range from excellent to average.

TABLE IV: SPM RESULT FOR ENGLISH LANGUAGE SUBJECT

\begin{tabular}{ccc}
\hline Result & $\begin{array}{r}\text { Frequency (f) } \\
\mathbf{N = 1 6 0}\end{array}$ & Percentage (\%) \\
\hline 1A & 13 & 8.1 \\
2A & 40 & 25.0 \\
3B & 35 & 21.9 \\
4B & 19 & 11.9 \\
5C & 35 & 21.9 \\
6C & 17 & 10.6 \\
7D & 1 & 0.6 \\
8E & 0 & 0 \\
9G & 0 & 0 \\
\hline
\end{tabular}

TABLE V: SPM GRADING SCALE

\begin{tabular}{|l|c|}
\hline \multicolumn{1}{|c|}{ Mastery Level } & Grade Result \\
\hline Excellent & $1 \mathrm{~A}$ \\
\hline Very Good & $2 \mathrm{~A}$ \\
\hline Pass with Credit & $3 \mathrm{~B}$ \\
\hline Pass with Credit & $4 \mathrm{~B}$ \\
\hline Pass with Credit & $5 \mathrm{C}$ \\
\hline Pass with Credit & $6 \mathrm{C}$ \\
\hline Pass & $7 \mathrm{D}$ \\
\hline Pass & $8 \mathrm{E}$ \\
\hline Failure & $9 \mathrm{G}$ \\
\hline
\end{tabular}

\section{B. Factors of Foreign Language Anxiety (FLA)}

FLA was assessed from the results obtained from FLCAS. Respondents were found to experience a moderate degree of FLA. Items loaded on the highest mean were chosen to detect factors provoking anxiety the most.

Table VI shows respondents' level of CA. Among items identified to score the highest mean are item 32 "I would probably feel comfortable around native speakers of English" (mean =3.32) and item 14 "I would not be nervous speaking in English with native speakers" (mean = 3.31). Items identified to score the lowest mean are item 9 "I start to panic when I have to speak without preparation in my English class" $($ mean $=2.58)$ and item 15 "I get upset when I don't understand what the English lecturer is correcting" (mean = 2.59). In general, the data reveals learners' CA to be at a moderate level $($ mean $=2.96)$. The interview revealed students are less anxious to communicate with native speakers as they believe native speakers can offer help when they are lost for words.

TABLE VI: LEARNERS' COMMUNICATION APPREHENSION

\begin{tabular}{|l|c|c|c|}
\hline \multicolumn{1}{|c|}{$\begin{array}{c}\text { Communication } \\
\text { Apprehension }\end{array}$} & Mean & $\begin{array}{c}\text { Std. } \\
\text { Deviation }\end{array}$ & Interpretation \\
\hline $\begin{array}{l}\text { 1) I never feel quite sure of } \\
\text { myself when I am speaking }\end{array}$ & 2.88 & 1.10 & Moderate \\
$\begin{array}{l}\text { English in my English } \\
\text { class. }\end{array}$ & & & \\
\hline
\end{tabular}




\begin{tabular}{|l|l|l|l|}
\hline $\begin{array}{l}\text { 3) I don't worry about } \\
\text { making mistakes in English } \\
\text { class. }\end{array}$ & 2.77 & 1.25 & Moderate \\
\hline $\begin{array}{l}\text { 4) It frightens me when I } \\
\text { don't understand what the } \\
\text { lecturer is saying in } \\
\text { English. }\end{array}$ & 3.13 & 1.13 & Moderate \\
\hline $\begin{array}{l}\text { 9) I start to panic when I } \\
\text { have to speak without } \\
\text { preparation in my English } \\
\text { class. }\end{array}$ & 2.58 & 1.25 & Moderate \\
\hline $\begin{array}{l}\text { 14) I would not be nervous } \\
\text { speaking in English with } \\
\text { native speakers. }\end{array}$ & 3.31 & 1.09 & Moderate \\
\hline $\begin{array}{l}\text { 15) Iget upset when I don't } \\
\text { understand what the } \\
\text { English lecturer is } \\
\text { correcting. }\end{array}$ & 2.59 & 1.15 & Moderate \\
\hline $\begin{array}{l}\text { 18) I feel confident when I } \\
\text { speak using English in my } \\
\text { English class. }\end{array}$ & 3.12 & 1.01 & Moderate \\
\hline $\begin{array}{l}\text { 20) I can feel my heart } \\
\text { pounding when I'm going } \\
\text { to be called on in my } \\
\text { English class. }\end{array}$ & 2.84 & 1.24 & Moderate \\
\hline $\begin{array}{l}\text { 27) I get nervous and } \\
\text { confused when I am } \\
\text { speaking in my English } \\
\text { class. }\end{array}$ & 3.21 & 1.04 & Moderate \\
\hline $\begin{array}{l}\text { 29) I get nervous when I } \\
\text { don't understand every } \\
\text { word the English lecturer is } \\
\text { saying. }\end{array}$ & 3.04 & 1.09 & Moderate \\
\hline $\begin{array}{l}\text { 30) I feel overwhelmed by } \\
\text { the number of rules you } \\
\text { have to learn to speak } \\
\text { English. }\end{array}$ & 3.03 & 1.04 & \\
\hline $\begin{array}{l}\text { 32) I would probably feel } \\
\text { comfortable around native } \\
\text { speakers of English. }\end{array}$ & 3.32 & 1.06 & \\
\hline $\begin{array}{l}33) \text { I get nervous when the } \\
\text { English lecturer asks } \\
\text { questions which I haven't } \\
\text { prepared in advance. }\end{array}$ & 2.71 & 1.10 & \\
\hline Total & & & \\
\hline
\end{tabular}

Table IX shows learners' FLC. Among items identified scoring the highest mean are item 5 "It wouldn't bother me at all to take more English classes" (mean = 3.65) and item 17 "I often feel like not going to my English class" (mean = 3.62). Meanwhile, among items scoring the lowest mean are item 16 "Even if I am well prepared for my English class, I feel anxious about it" (mean $=2.56$ ), item 12 "In my English class, I can get so nervous I forget things I know" (mean $=2.95)$ and item 25 "English class moves so quickly I worry about getting left behind" (mean $=2.95)$. In general, data reveals learners' FLC to be at a moderate level (mean $=3.25)$.

Table VII reveals learners' TA and among items found to score the highest mean are item 22 "I don't feel pressure to prepare very well for my English class" (mean $=3.45)$ and item 21 "The more I study for an English test, the more confused I get" (mean = 3.36). Meanwhile, among items with the lowest mean score are item 10 "I worry about the consequences of failing my English class" (mean $=2.22)$ and item 8 "I am usually at ease during tests in my English class" $($ mean $=3.03)$. Respondents, in general, experience a moderate degree of TA $($ mean $=3.01)$. The interview revealed learners are not pressured to prepare well for English tests as they place greater focus on the technical subjects.
Table VIII displays every item for FNE to be moderate and low. Among items identified to score the highest mean are item 2 "I don't worry about making mistakes in English class" (mean $=3.33)$ and item 19 "I am afraid that my English lecturer is ready to correct every mistake I make" (mean = 3.31). Items identified to have the lowest mean are item 7 "I keep thinking that other students are better in English language than I am" (mean = 2.21) and item 23 "I always feel that the other students speak English better than I do" (mean = 2.27). In general, learners' FNE is at a moderate level (mean $=$ 2.78). Interestingly, learners were not worried about making mistakes but rather were more worried of the language instructor who is ready to correct every mistakes.

TABLE VII: LEARNERS' TEST ANXIETY

\begin{tabular}{|l|c|c|c|}
\hline \multicolumn{1}{|c|}{ Test Anxiety } & Mean & $\begin{array}{c}\text { Std. } \\
\text { Deviation }\end{array}$ & Interpretation \\
\hline $\begin{array}{l}\text { 8) I am usually at ease } \\
\text { during tests in my English } \\
\text { class. }\end{array}$ & 3.03 & 1.07 & Moderate \\
\hline $\begin{array}{l}\text { 10) I worry about the } \\
\text { consequences of failing my } \\
\text { English class. }\end{array}$ & 2.22 & 1.12 & Low \\
\hline $\begin{array}{l}\text { 21) The more I study for an } \\
\text { English test, the more } \\
\text { confused I get. }\end{array}$ & 3.36 & 1.17 & Moderate \\
\hline $\begin{array}{l}\text { 22) I don't feel pressure to } \\
\text { prepare very well for my } \\
\text { English class. }\end{array}$ & 3.45 & 1.00 & Moderate \\
\hline Total & 3.01 & 0.71 & Moderate \\
\hline
\end{tabular}

TABLE VIII: LEARNERS' FEAR OF NEGATIVE EVALUATION

\begin{tabular}{|c|c|c|c|}
\hline $\begin{array}{c}\text { Fear of Negative } \\
\text { Evaluation }\end{array}$ & Mean & $\begin{array}{c}\text { Std. } \\
\text { Deviation }\end{array}$ & Interpretation \\
\hline $\begin{array}{l}\text { 2) I don't worry about } \\
\text { making mistakes in English } \\
\text { class. }\end{array}$ & 3.33 & 1.12 & Moderate \\
\hline $\begin{array}{l}\text { 7) I keep thinking that other } \\
\text { students are better in } \\
\text { English language than I am. }\end{array}$ & 2.21 & 1.05 & Low \\
\hline $\begin{array}{l}\text { 13) It embarrasses me to } \\
\text { volunteer answers in my } \\
\text { class. }\end{array}$ & 2.73 & 1.25 & Moderate \\
\hline $\begin{array}{l}\text { 19) I am afraid that my } \\
\text { English lecturer is ready to } \\
\text { correct every mistake I } \\
\text { make. }\end{array}$ & 3.31 & 1.05 & Moderate \\
\hline $\begin{array}{l}\text { 23) I always feel that the } \\
\text { other students speak } \\
\text { English better than I do. }\end{array}$ & 2.27 & 1.11 & Low \\
\hline $\begin{array}{l}24) \quad \text { I feel very } \\
\text { self-conscious } \\
\text { speaking English in front of } \\
\text { other students. }\end{array}$ & 2.83 & 1.17 & Moderate \\
\hline $\begin{array}{l}\text { 31) I am afraid that the } \\
\text { other students will laugh at } \\
\text { me when I speak English. }\end{array}$ & 2.76 & 1.26 & Moderate \\
\hline Total & 2.78 & 0.71 & Moderate \\
\hline
\end{tabular}

Fig. 2 displays the mean scores for the four components of FLA as derived from FLCAS. Based on the results, it is obvious that FLC is the highest (mean $=3.25)$ across all FLA components. This is followed by TA (mean $=3.01)$, CA $($ mean $=2.96)$ and FNE $($ mean $=2.78)$. Learners were found to be reluctant to attend English class $($ mean $=3.62)$ and feel more nervous attending English class compared to other classes $($ mean $=3.46)$. However, the study revealed learners do not have fear to take more English class in future (mean = 
3.65) and are not pressured to make good preparations before class $($ mean $=3.45)$.

Though moderate, respondents reported in the interview that the anxiety they experience - to a certain degree - affects and hinders their learning process.

TABLE IX: LEARNERS' FEAR OF LANGUAGE CLASS

\begin{tabular}{|l|c|c|c|}
\hline \multicolumn{1}{|c|}{ Fear of Language Class } & Mean & $\begin{array}{c}\text { Std. } \\
\text { Deviation }\end{array}$ & Interpretation \\
\hline $\begin{array}{l}\text { 5) It wouldn't bother me at } \\
\text { all to take more English } \\
\text { classes. }\end{array}$ & 3.65 & 1.22 & Moderate \\
\hline $\begin{array}{l}\text { 6) During English class, I } \\
\text { find myself thinking about } \\
\text { things that have nothing to } \\
\text { do with the language. }\end{array}$ & 3.21 & 1.10 & Moderate \\
\hline $\begin{array}{l}\text { 11) I don't understand why } \\
\text { some people get so upset } \\
\text { over English classes. }\end{array}$ & 3.44 & 1.01 & Moderate \\
\hline $\begin{array}{l}\text { 12) In my English class, I } \\
\text { can get so nervous I forget } \\
\text { things I know. }\end{array}$ & 2.95 & 1.09 & Moderate \\
\hline $\begin{array}{l}\text { 16) Even if I am well } \\
\text { prepared for my English } \\
\text { class, I feel anxious about } \\
\text { it. }\end{array}$ & 2.56 & 1.10 & Moderate \\
\hline $\begin{array}{l}\text { 17) I often feel like not } \\
\text { going to my English class. }\end{array}$ & 3.62 & 1.26 & Moderate \\
\hline $\begin{array}{l}\text { 25) English class moves so } \\
\text { quickly I worry about } \\
\text { getting left behind. }\end{array}$ & 2.95 & 1.09 & Moderate \\
\hline $\begin{array}{l}\text { 26) I feel more tense and } \\
\text { nervous in my English class } \\
\text { than in my other class. }\end{array}$ & 3.46 & 1.09 & Moderate \\
\hline $\begin{array}{l}\text { 28) When I'm on my way to } \\
\text { English class, I feel very } \\
\text { sure and relaxed. }\end{array}$ & 3.37 & 0.94 & \\
\hline Total & 3.25 & & \\
\hline
\end{tabular}

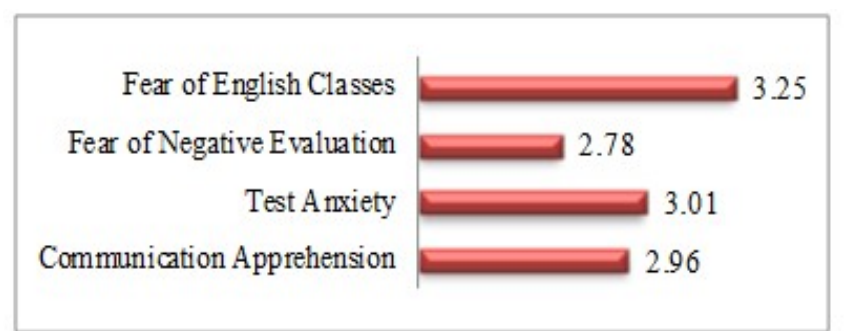

Fig. 2. Factors of FLA.

\section{Learners Strategies in Coping with FLA}

A descriptive analysis of frequency and percentage is used to analyse choices of strategies respondents employ to cope with FLA in English language classroom. The top six strategies are as shown in Fig. 3.

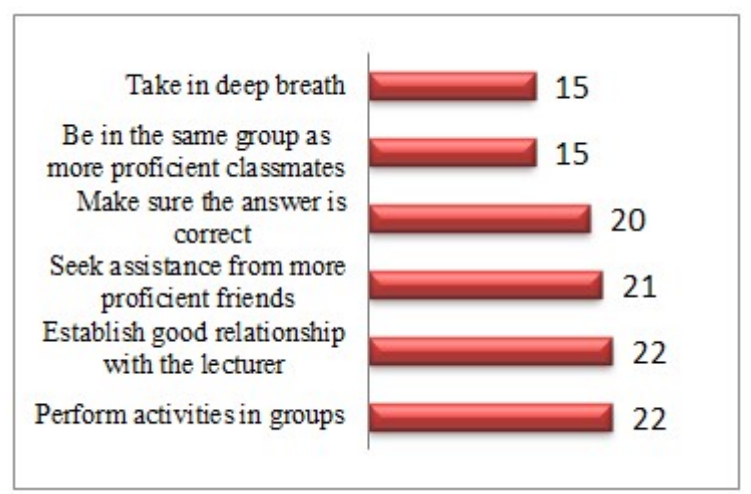

Fig. 3. Strategies most employed by learners to cope with FLA.
Fig. 3 shows the strategies most employed by respondents to cope with FLA. The results reveal respondents employing positive strategies in coping with FLA. From Fig. 3, it is obvious that the most popular strategies to cope with FLA are performing activities in groups and establishing good relationship with the lecturer. Out of 24 respondents, 22 $(91.7 \%)$ selected these strategies while only $2(8.3 \%)$ did not. Learners reported to prefer working together and seeking assistance from more proficient classmates. However, from the interview, respondents who did not prefer working in groups explained that they can feel intimidated when placed in a group dominated by more proficient friends. Nonetheless, they admitted to feel more secure knowing that friends are available to assist them when they encounter difficulties. Findings correlate those of [17], [20] and [26] to suggest structured group learning activities, group work, pair work, games and simulations as strategies to create a more relaxed and less threatening learning environment. [20] concluded FLA can be reduced when learners work in small groups, facilitated by classmates who are more proficient in English.

Fig. 4 reveals the least popular strategies employed by learners to deal with FLA. The study also revealed ten least popular coping strategies among respondents as exemplified in Fig. 4. Only $1(4.2 \%)$ respondent reported to resort to the strategy of "Not asking any questions", 1 (4.2\%) "Not paying attention", and 1 (4.2\%) "Not showing interest". 22 (91.7\%) of the respondents reported to prefer working in groups as opposed to $7(29.2 \%)$ who preferred working individually. Other strategies listed in the checklist include, "Place hope on proficient classmates to feed the answers", "Make preparations before attending class", "Volunteer to answer questions", "Not worry about getting laughed at for making mistakes", "Attempt to complete class activities individually". In contrast to the study done by [17], respondents in this study employed all five strategies as categorised by [16] to include Resignation strategy. However, these strategies were not the popular choices.

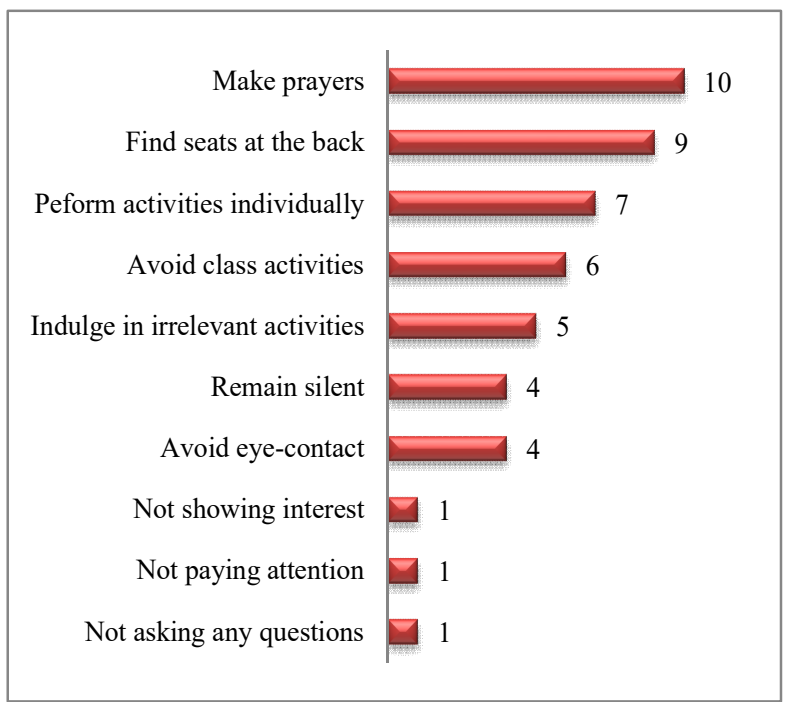

Fig. 4. Strategies least employed by learners to cope with FLA.

Based on the interview, respondents revealed the strategies taken were either done intentionally or spontaneously, depending on the degree of anxiety they experienced. Interestingly, proficient learners admitted to experience a 
high degree of anxiety as they believed the language instructor and classmates would place a higher expectation towards them. With the pressure to meet the high expectation and to prove to fellow classmates they are better, proficient learners simply tripled their anxiety level.

\section{CONCLUSION AND RECOMMENDATIONS}

FLA, to a certain degree, affects learners' language learning process. Regardless the degree of anxiety learners experience in L2 classrooms, the presence of FLA is enough to interfere with learning process and hinder learners from participating actively in class activities. Components of FLA such as CA and FNE can affect learners' self-conscience and lead them into thinking twice before speaking. In extreme cases, words never leave the tip of the learners' tongue, thus, affecting their overall performance in class.

Learners who experience FLA adopt positive and negative strategies as means to cope with this psychological constraint. These strategies can be facilitating and debilitating. By being aware of the strategies, language instructors can assess learners' FLA and help them find ways to deal with it. By establishing better interaction with the learners, language instructors can dig into learners' experience to point out effective FLA coping strategies. Learners must be assured that the anxiety they experience is normal and that there are ways to help reduce and cope with it. Learners must constantly be reminded that anxiety, if well-controlled, can be positive in their language learning process.

The existence of FLA must be recognized and rightly addressed to ensure effectiveness of language teaching. To assist learners in language learning and enhance their confidence in using the language, language instructors must be aware of the existence of FLA. By acknowledging its presence, language instructors can adjust teaching approach to create less threatening and less intimidating learning environment. Over-emphasis on grammar can cause anxiety whenever learners attempt to communicate so language instructors should allow learners with more time before they speak and welcome mistakes as part of the learning process.

Further studies are thus imperative to find more ways to measure FLA and gain deeper insights into this phenomenon. Findings should be able to provide language instructors with models and techniques to improve language teaching. Module makers must also consider FLA as a psychological constraint when designing language syllabus in order to make teaching more effective and meaningful.

\section{REFERENCES}

[1] E. K. Horwitz, M. B. Horwitz, and J. Cope, "Foreign language classroom anxiety," The Modern Language Journal, vol. 70, no. 2, $125-132,1986$

[2] Z. Dörnyei, The Psychology of the Language Learner: Individual Differences in Second Language Acquisition, Routledge, 2005.

[3] E. Horwitz, "Language anxiety and achievement," Annual Review of Applied Linguistics, vol. 21, no. 1, pp. 112-126, 2001.

[4] P. D. MacIntyre, "Language anxiety: A review of the research for language teachers," Affect in Foreign Language and Second Language Learning: A Practical Guide to Creating a Low-Anxiety Classroom Atmosphere, pp. 24-45, 1999.

[5] P. D. MacIntyre and R. C. Gardner, "Methods and results in the study of anxiety and language learning: A review of the literature," Language Learning, vol. 41, no. 1, pp. 85-117, 1991.
[6] R. L. Oxford, "Anxiety and the language learner: new insights," Affect in Language Learning, pp. 58-67, 1999.

[7] D. J. Young, "Affect in foreign language and second language learning: A practical guide to creating a low-anxiety classroom atmosphere," The USA: McGraw-Hill Companies, 1999.

[8] A. J. Onwuegbuzie, P. Bailey, and C. E. Daley, "Factors associated with foreign language anxiety," Applied Psycholinguistics, vol. 20, pp. 207-239, 1999.

[9] T. Scovel, Learning New Languages: A Guide to Second Language Acquisition, Boston: Heinle \& Heinle, 2001.

[10] G. Spielmann and M. L. Radnofsky, "Learning language under tension: New directions from a qualitative study," The Modern Language Journal, vol. 85, no. 2, pp. 259-278, 2001.

[11] R. Clément, R. C. Gardner, and P. C. Smythe, "Social and individual factors in second language acquisition," Canadian Journal of Behavioural Science/Revue Canadienne des Sciences $d u$ Comportement, vol. 12, no. 4, p. 293, 1980.

[12] D. J. Young, "An investigation of students' perspectives on anxiety and speaking," Foreign Language Annals, vol. 23, pp. 539-553, 1990.

[13] C. M. Campbell and J. A. Ortiz, "Helping students overcome foreign language anxiety: A foreign language anxiety workshop," in Language Anxiety: From Theory and Research to Classroom Implications, E. K. Horwitz \& D. J. Young, Eds. Englewood Cliffs, NJ: Prentice Hall, 1991, pp. 153-168.

[14] T. Dvorak, "Writing in the Foreign Language. Listening, Reading, and Writing: Analysis and Application," in Proc. Conference on the Teaching of Foreign Languages, B. H. Wing, Ed. Middlebury, Vermont: Northeast, 1986, pp. 145-167.

[15] D. S. Kondo and Y. Y. Ling, "Strategies for coping with language anxiety: The case of students of English in Japan," ELT Journal, vol. 58 , no. 3, pp. 258-265, 2004.

[16] A. Marwan, "Investigating students' foreign language anxiety," Malaysian Journal of ELT Research, vol. 3, pp. 37-55, 2007.

[17] T. L. Nagahashi. (2007). Techniques for reducing foreign language anxiety: Results of a successful intervention study. [Online]. pp. 53-60. Available: http://air.lib.akitau.ac.jp/dspace/bitstream/10295/547/3/kk9-6.pdf

[18] Y. Nuranifar, "Strategies to cope with second language learning Anxiety: The case of Iranian pre-university students," Journal of Novel Applied Sciences, vol. 3, no. 1493-1502, 2014.

[19] I. R. Lucas, E. Miraflores, and D. Go, "English language learning anxiety among foreign language learners in the Philippines," Philippine ESL Journal, vol. 7, no. 94-119, 2011.

[20] K. lizuka, "Learner coping strategies for foreign language anxiety," in Proc. JALT2009 Conference Proceeding, A. M. Stoke, Ed. 2010, pp. 103-112.

[21] N. E. Pappamihiel, "English as a second language students and English language anxiety. Issues in the mainstream classroom," Proquest Education Journal, vol. 36, no. 3, pp. 327-355, 2002.

[22] Y. Aida, "Examination of Horwitz, Horwitz, and Cope's construct of foreign language anxiety: The case of students of Japanese," The Modern Language Journal, vol. 78, pp. 155-167, 1994.

[23] L. Ganschow and R. L. Sparks, "Anxiety about foreign language learning among high school women," The Modern Language Journal, vol. 80, pp. 199-212, 1996.

[24] R. A. Von WÖrde, "An investigation of students' perceptions of foreign language anxiety," Doctoral dissertation, George Mason University, 1998.

[25] W. Zarina, W. Zakaria et al., "Kajian tahap keresahan di kalangan pelajar bahasa asing terhadap mata pelajaran bahasa asing," Pusat Pengurusan Penyelidikan Universiti Teknologi Malaysia, 2007.

[26] S. Aydin, "An investigation on the language anxiety and fear of negative evaluation among Turkish EFL learners," Asian EFL Journal, vol. 8, no. 4, pp. 421-444, 2008.

[27] N. Idri, "Sources of FNE among first year LMD1 students of Abderrahmane Mira University," Procedia-Social and Behavioral Sciences, vol. 29, pp. 1932-1941, 2011.

[28] M. Liu and W. Huang, "An exploration of foreign language anxiety and English learning motivation," Education Research International 2011, Article ID 493167.

[29] K. Yaikhong and S. Usaha, "A measure of EFL public speaking class anxiety: Scale development and preliminary validation and reliability," English Language Teaching, vol. 5, no. 12, pp. 23-35, 2012.

[30] Z. Suleimenova, "Speaking anxiety in a foreign language classroom in Kazakhstan," Procedia - Social and Behavioral Sciences, vol. 93, pp. 1860-1868, 2013. 


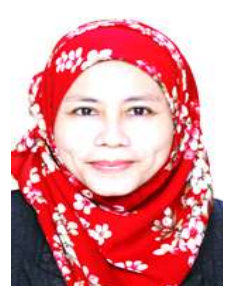

Wan Iman Wan Salim is currently pursuing for a $\mathrm{PhD}$ in Applied Comparative Linguistics from Universiti Putra Malaysia (UPM). Born in September 1974 in Cairo, Egypt, the author received early primary and secondary education in Malaysia and Scotland in 1980-1991. The author obtained B.HSc. in English Language and Literature from International Islamic University Malaysia (IIUM) in 1996/97 before pursuing for M.HSc. in Literary Studies from the same institution (1998/2000). Currently, as part of the objectives of her research, the author is finishing her book that shares tips and techniques of helping learners deal with anxiety in English language learning.

To kick start her career in 1999, Ms. Iman served as a tutor with Universiti Putra Malaysia until 2003. Since 2006 until now, she has been teaching English at University Kuala Lumpur Malaysia France Institute (UniKL MFI). She has the experience of teaching - on part-time basis - various English subjects at several local higher tertiary education institutions such as Universiti Science Islam Malaysia (USIM), Universiti Tenaga Nasional (UNITEN), and Taylor's College. Occasionally, she receives invitation as a trainer for several government and private agencies such as Selangor State Health Department, Pest Control Association Malaysia and Malaysia Taxi Drivers Association. She is also a member of Asia TEFL and is passionate about education psychology, language learning strategies and motivation in language learning.

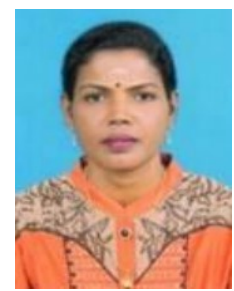

Vijayaletchumy Subramaniam is an associate professor in the Department of Malay Language, Faculty of Modern Languages and Communication, Universiti Putra Malaysia. She specializes in Applied Linguistics, Psycholinguistics, Translation, and Second Language Acquisition. She is particularly interested in the relationship between language, communication and society. She has won several awards for her research on dyslexia: Invention, Innovation, and Technology Exhibition (ITEX) 2011 (Gold); Invention, Innovation, and Technology Exhibition 2011 (Best Award: WIPO); International Conference and Exposition on Inventions of Institutions of Higher Learning (PECIPTA) 2011 (Gold); Malaysia Technology Expo (MTE) 2012 (Gold).

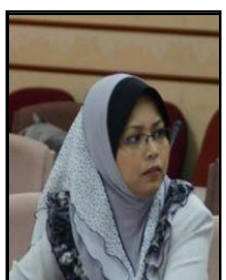

Arbaayah Ali Termizi is an associate professor in the Department of English, Faculty of Modern Languages and Communication, Universiti Putra Malaysia. Her prominent research focus is in the Shakespearean playtexts. She is also interested in interdisciplinary studies of contemporary issues in the world of English Literature. 